\title{
Development, reproduction, host range and geographical distribution of the variegated caper bug Stenozygum coloratum (Hemiptera: Heteroptera: Pentatomidae)
}

\author{
Shahar SAMRA ${ }^{1,2}$, Murad GHANIM $^{1}$, Alex PROTASOV $^{1}$ and Zvi MENDEL ${ }^{1}$ \\ ${ }^{1}$ Department of Entomology, Volcani Center, P.O. Box 6, Bet Dagan 50250, Israel; e-mails: shaharsm@agri.gov.il; \\ ghanim@agri.gov.il; protasov@agri.gov.il; zmendel@agri.gov.il \\ ${ }^{2}$ Faculty of Agriculture, Hebrew University of Jerusalem, Rehovot 76100, Israel
}

Key words. Heteroptera, Pentatomidae, Stenozygum coloratum, Capparis spp., development, distribution, egg, host range, larva, Ooencyrtus pityocampae, pine processionary moth, Thaumetopoea wilkinsoni, variegated caper bug

\begin{abstract}
The variegated caper bug (CB) Stenozygum coloratum (Klug, 1845) is common in the Eastern Mediterranean region and a minor agricultural pest. CB eggs were recently shown to serve as alternative hosts for Ooencyrtus pityocampae Mercet, 1921, an important natural enemy of the pine processionary moth (PPM) Thaumetopoea wilkinsoni Tams, 1924 (Lepidoptera: Notodontidae). In this study various aspects of the life history of $\mathrm{CB}$ were studied, including its distribution, host range, development, reproduction and ability to develop on various cultivated species of plants. CB occurs in almost all areas and habitats in Israel, except in the coldest regions, attacking several caper species (Capparis spp.). When reared on Capparis zoharyi at $25^{\circ} \mathrm{C}$, one generation lasted 6 weeks and females laid a single 12-egg cluster every 3 days. Decreases in temperature, but not changes in day length, terminated reproductive activity. $\mathrm{CB}$ nymphs survived for up to three months, or even completed their development, on some agricultural plants. However, reproductive activity was initiated only if adults were fed capers. These findings emphasize the importance of capers in the CB life cycle and account for why other plants are rarely attacked. These plants may serve as a temporary refuge for CB when capers are scarce or unsuitable, mainly late in the season. Morphology of developmental stages, egg deposition, cannibalistic behaviour, sex ratio and effects of temperature on egg production were also studied. The possibility of using CB for enhancing the biological control of PPM is discussed.
\end{abstract}

\section{INTRODUCTION}

The superfamily Pentatomoidea (Heteroptera) includes 16 families and about 1300 genera, with over 7200 species, of which many are polyphagous plant sap suckers (Henry, 2009; Rider, 2013). Some species are known as serious pests and are well studied (Panizzi, 1987, 1997; Panizzi et al., 2000; Schaefer \& Panizzi, 2000), whereas the biology of many non-harmful species remains largely unexplored, among them, the approximately 40 members of the genus Stenozygum Fieber, 1861 (Pentatomidae: Strachiini). About 10 years ago it was discovered that the eggs of one of the species in the genus Stenozygum, the variegated caper bug (CB) S. coloratum (Klug, 1845), are parasitized by Ooencyrtus pityocampae Mercet, 1921 (OP) (Hymenoptera: Encyrtidae) (Mizrachi, 2006). This parasitoid wasp is well known as one of the commonest natural enemies of the pine processionary moth (PPM) Thaumetopoea pityocampa Denis \& Schiffermüller, 1775 / T. wilkinsoni Tams, 1924 (Lepidoptera: Notodontidae) species complex (Battisti, 1989; Tsankov, 1990; Kitt \& Schmidt, 1993; Schmidt et al., 1999, 1997), a major pest of pine forests throughout the Mediterranean basin (Wilkinson, 1926; Battisti, 1988; Halperin, 1990; Carus, 2004; Kanat et al., 2005; Jacquet et al., 2013; Tamburini et al., 2013). Our preliminary study of OP emerging from $\mathrm{CB}$ eggs indicated that these eggs serve as alternative hosts for OP populations in spring and summer, when PPM eggs are absent. Thus, CB might be important for the survival of OP populations in eastern
Mediterranean pine forests. The potential importance of $\mathrm{CB}$, coupled with the poor knowledge of its biology, drew our attention to this bug and resulted in the following study of this species. The assumption is that knowledge of this species may be useful for enhancing the natural control of PPM. Furthermore, CB is also a minor pest of many agricultural crops (Bodenheimer, 1930) and the suitability of these plants as hosts for CB is unclear (see below). Therefore, improved understanding of the occurrence of $\mathrm{CB}$ on agricultural plants might help reduce the damage caused by this bug. To the best of our knowledge, this is the first time the biology of $\mathrm{CB}$ has been studied.

The CB belongs to the subgenus Stenozygum s. str. (Rider, 2006). In the $19^{\text {th }}$ and $20^{\text {th }}$ centuries the genus Stenozygum was reclassified several times, and CB itself also appeared under several names, e.g., Cimex coloratus, Stenozygum variegatum, Strachia variegata, Nitilia variegata and Pseumatocoris ignitus (reviewed by Ahmad \& Khan, 1983; Rider, 2006; Robertson, 2009).

Ahmad \& Kahn (1983) mention that "species of the genus Stenozygum have long been known to be associated with Capparis spp. (Capparaceae) of medicinal importance, the mustard plant Brassica campestris L. (Brassicaceae), a source of cooking oil of medicinal importance and the fodder plant Medicago sativa L. (Fabaceae)". Plants belonging to other families, such as Solanaceae, Alliaceae, Resedaceae and Gyrostemonaceae, are also mentioned (Ghauri, 1972; Rider, 2006; Carapezza, 2011), although it 
should be noted that it is not always clear whether these host plants are suitable for development and reproduction, or are merely used for ocassional feeding or resting (see also Burckhardt et al., 2014). CB commonly occurs in open areas in the Middle East, mainly feeding on caper plants, Capparis spinosa L. (Kugler, 1985). However, it is unclear which other caper species in this genus, if any, are used by the bug. As mentioned above, CB is also occasionally found in agricultural areas, where it is a minor pest. Bodenheimer (1930) was the first to report the bug from Israel and record its economic importance in the East Mediterranean region. Bodenheimer (1930), and later also Avidov (1961) and Swirski et al. (2002), provide lists of agricultural plants on which this bug is recorded. However, it is known that the food plants of adults and nymphs of other species of pentatomid differ and that some plants are unsuitable for nymphal development but are used as a food source (Panizzi, 1997). The frequent inadequate attribution of host status was stressed recently by Burckhardt et al. (2014). Burckhardt et al. further suggest the use of the term 'host plants' be restricted to plants on which a species can complete its immature to adult life cycle, and distinguish them from plants on which adults of a species overwinter, shelter, or feed but do not reproduce. In the case of $\mathrm{CB}$ and the agricultural plants mentioned above, both the adults and nymphs feed on these plants and both Bodenheimer (1930) and Avidov (1961) assume that CB is able to develop and reproduce on these plants, whereas Swirski et al. (2002) consider that plants other than capers are utilized only occasionally for feeding, when physiologically suitable capers are scarce or unavailable (mainly at the end of summer). Nonetheless, as the overall damage caused by $\mathrm{CB}$ is small it attracted little attention, and no attempt was made to determine the suitability of these plants for the development of $\mathrm{CB}$ nymphs. Consequently, their host status remains questionable.

In the present study we review the data on $\mathrm{CB}$ and conduct field and laboratory studies of various aspects of its life cycle. The objectives were: (1) to determine the distribution of CB globally (based on a literature survey) and locally (based on field surveys in Israel); (2) to record egg and nymphal development and survival, reproductive activity and behavior of $\mathrm{CB}$, and provide a basic description of all life history stages; and (3) to compile a host-plant list and determine the host range by using data from the literature and new data collected in the field and laboratory, and, more specifically, determine whether CB is able to develop on the various agricultural plants on which it is occasionally recorded.

\section{MATERIAL AND METHODS}

\section{Distribution}

The distribution of CB in Israel was determined by field excursions to various locations throughout the country. These surveys was carried out in 2007, 2011 and 2012 and included most of the climatic zones in Israel (see Fig. 1 for the locations studied). In addition, the presence of CB presence in southern Turkey was recorded during a short field excursion (Hatay, Adana and Mersin provinces) over the period $24-29^{\text {th }}$ June 2013 . The global distri- bution of CB, and that of the genera Stenozygum and Capparis, was also revised and presented in brief, and the data summarized in order to draw the geographical borders for these three genera.

\section{Life history study}

Unless stated otherwise, rearing and experiments were conducted at $25^{\circ} \mathrm{C}, 40-60 \%$ relative humidity and under a $14 \mathrm{~L}: 10 \mathrm{D}$ photoperiod. Some field data on various aspects of CB biology, e.g., sex ratio and egg laying, were also recorded, described and compared with laboratory data.

\section{Rearing}

About 100 individuals of CB were collected from Eshta'ol Forest (Central Israel, 31 ${ }^{\circ} 48^{\prime} 23^{\prime \prime} \mathrm{N}$ ) in May 2012 and used to establish a laboratory culture. We used plastic rearing cages $(30 \times 35 \times$ $15 \mathrm{~cm}$ ) with four $30 \mathrm{~cm}^{2}$ openings for ventilation. The openings were covered with 50-mesh net. Individuals were fed fresh caper (C. zoharyi) twigs placed in plastic bottles $(10 \mathrm{~cm}$ high, $150 \mathrm{ml}$ volume) filled with water. Food was replaced twice a week. A cardboard sheet (approximately $20 \times 10 \mathrm{~cm}$ ) was placed inside each cage to provide an additional resting surface and shelter for the bugs.

\section{Measurements and illustrations of the various life stages}

The hind tibia and total body lengths of 10 individuals of each of the life stages (adults and nymphal stages) collected from the stock culture were measured. Ten egg clusters, randomly selected from the stock culture, were used for measuring egg height and diameter and the length of egg-clusters. Measurements were made using a stereomicroscope, and photographs were taken with a Coolpix 5400 camera (Nikon, Tokyo, Japan).

Egg hatch and information on egg laying behaviour

For assessing percentage egg hatch, 48 egg clusters, comprising a total of 575 eggs, were collected from the stock culture. The number of eggs that hatched was recorded and the unhatched eggs were dissected to determine whether they were undeveloped or contained a dead nymph (an indication that the egg was fertile). Information on egg laying behaviour, mostly the location of egg clusters, was also recorded.

\section{Development and host range}

The development of $\mathrm{CB}$ was first studied using Capparis zoharyi (syn. C. hierosolymitana, Danin, 2010) as the food source. This plant was chosen because it is the dominant species of caper in Israeli pine forests and our field surveys revealed it is frequently attacked by this bug. The rearing was carried out in cylindrical plastic cages measuring $10 \mathrm{~cm}$ in diameter and $18 \mathrm{~cm}$ in height. A ventilation hole in the plastic lid and a second one in the wall, each approximately $25 \mathrm{~cm}^{2}$ in area, were covered with a 50-mesh net. Ten egg clusters, each comprising of 12 eggs, were used. Each egg cluster was placed separately inside a cage and the nymphs that hatched were reared to adulthood in the same cages. Individuals were fed in the same manner as in the rearing cages, apart from the plastic bottles, which were replaced by smaller plastic cups $(5 \mathrm{~cm}$ high) that fitted in the smaller cages. The cages were examined daily, and the duration of development and percentage survival were recorded for each developmental stage. The preoviposition period was recorded for 10 females taken from each of the cages used in the above experiment immediately after their last moult. These females were placed separately in cages of the same type and under the same conditions as above, each together with a single male taken from the stock culture, and the cages were examined daily for the presence of egg clusters.

The CB host range was based on a literature survey, field excursions in Israel and a short trip in Turkey (see above) in which we 


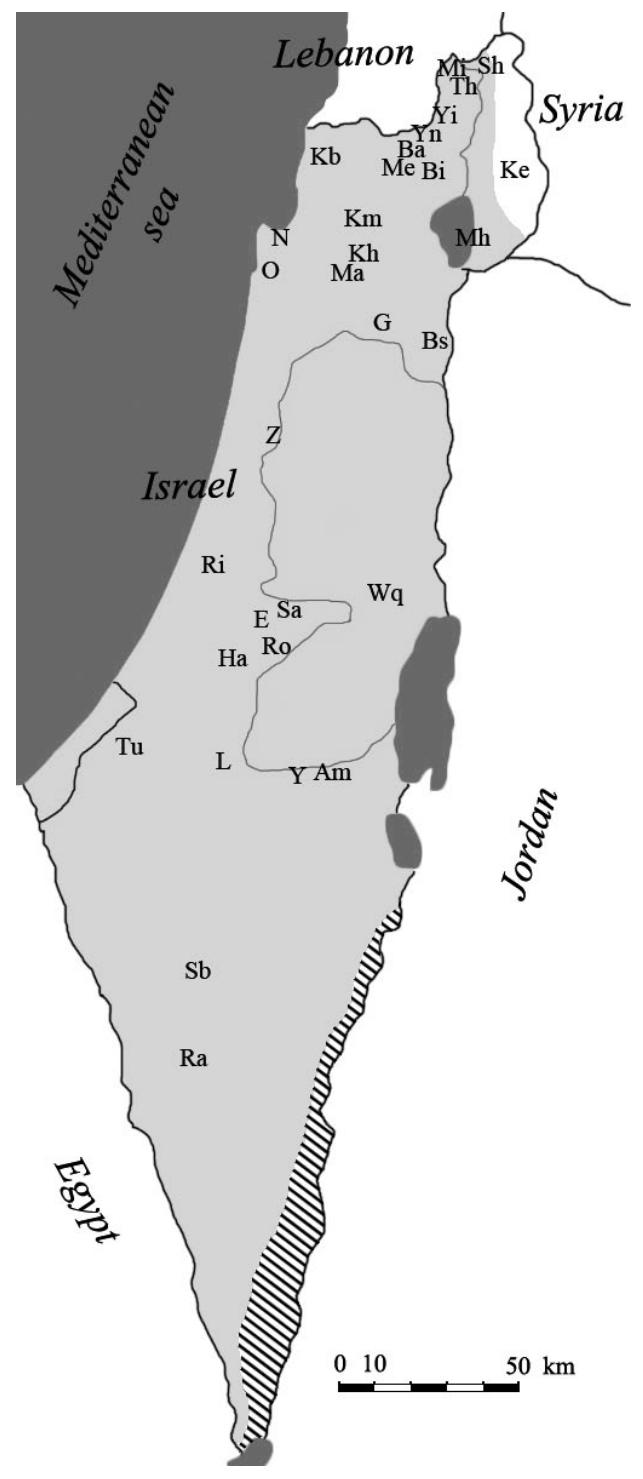

Fig. 1. Map of Israel showing the sites surveyed in 2007, 2011 and 2012 to determine the distribution of Stenozygum coloratum. Grey area is the estimated distribution in Israel, based on records of $S$. coloratum and the presence of its main host, Capparis spp. Hatched area (Arava Valley) was not studied, and no data are available for this region. Site abbreviations: Amasa Mountain (Am), Bar'am (Ba), Beit She'an (Bs), Birya (Bi), Eshta'ol (E), Gilboa (G), Kabri (Kb), Kfar Manda (Km), Keshet (K), Kfar Hahoresh (Kh), Lahav (L), Ma'alul (Ma), Meron (Me), Mevo Hama (Mh), Misgav Am (Ma), Nesher (N), Ofer (O), Rogalit (R), Sataf(S), Sde Boker (Sd), Shnir Stream (Sh), Tel Hay (Th), Tushia (Tu), Wadi Qelt (Wq), Yatir (Ya), Yiftach (Yi), Yir'on (Yn).

looked for new hosts. All plants on which the bug was recorded either in the literature or during the field surveys were recorded. As mentioned above, the bug is known to attack many species of agricultural plants belonging to various botanical families, but it is not clear whether it can develop and reproduce on these plants. Subsequently, an experiment was performed to determine the ability of CB to develop on five of these plants: Avocado Persea americana (Lauraceae); Citrus sp. (Rutaceae); common fig Ficus carica (Moraceae); Tomato Solanum lycopersicum and green pepper Capsicum annuum (Solanaceae).This experiment was carried out in a similar way and under the same conditions as the previous experiment, which recorded development on capers, and the data collected included nymphal survival and total duration of development on each plant. In cases where adults were obtained the experiment was continued in order to determine whether these adults were able to reproduce successfully on that particular plant. In addition, some of the adults were transferred to separate cages and reared on caper, to assess whether they were fertile, as indicated by the occurrence of offspring. This experiment was repeated three times for each plant species, and each repetition used a single cohort of 11 or 12 individuals obtained from a single egg cluster. CB nymphs developing on capers and nymphs that received only water (via plastic tubes sealed with cotton wool) served as controls.

Sex ratio

The adult sex ratio was determined using laboratory-reared individuals that developed from 108 nymphs that originated from the above experiment on their development on capers and were reared to adulthood. The adult sex ratio in the laboratory was compared with that of field-collected individuals. The latter comprised a total of 348 individuals that were sampled at the end of August 2012 at two sites: 81 individuals from Mt. Gilboa $\left(32^{\circ} 32^{\prime} 15^{\prime \prime} \mathrm{N}, 35^{\circ} 20^{\prime} 14^{\prime \prime} \mathrm{E}\right)$ and 267 individuals from Lahav Forest $\left(31^{\circ} 22^{\prime} 48^{\prime \prime} \mathrm{N}, 34^{\circ} 51^{\prime} 43^{\prime \prime} \mathrm{E}\right)$.

Determining the minimum temperature required for reproduction

This experiment was designed to determine the minimum temperature at which the bugs reproduced. A separate experiment (see below) was performed to gather quantitative data concerning the effect of temperature on fecundity. Two rearing cages, each containing 15 to 20 individuals, were placed in a rearing chamber at $25^{\circ} \mathrm{C}, 40-60 \% \mathrm{RH}$ and a $14 \mathrm{~L}: 10 \mathrm{D}$ photoperiod. The temperature was lowered gradually, by about $1^{\circ} \mathrm{C}$ every 5 days, starting from $25^{\circ} \mathrm{C}$, until egg laying ceased. Two additional rearing cages containing approximately the same number of individuals were kept under similar conditions, except that the temperature remained constant at $25^{\circ} \mathrm{C}$, which served as controls. 


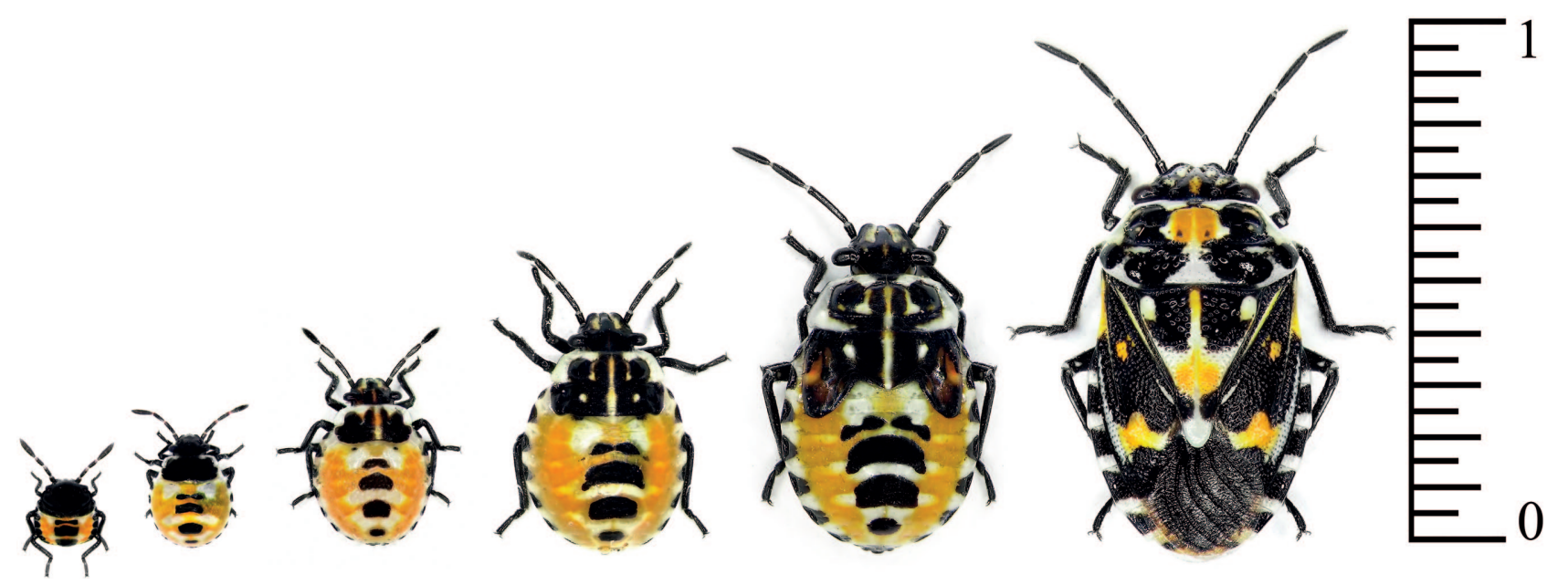

Fig. 3. Larval and adult stages of Stenozygum coloratum.

Natality and the effects of temperature, day length and mating

The effects of temperature and day length on fecundity, expressed in terms of the interval between laying egg clusters was studied at four treatments: 25 or $20^{\circ} \mathrm{C}$ (based on the results of the previous experiment that determined the minimum temperature for reproduction) and short- or long-day lengths (14L : 10D or $10 \mathrm{~L}: 14 \mathrm{D})$. Ten pairs of $\mathrm{CB}$, each consisting of a recently moulted female and male, were exposed to each temperature/ day-length regime. Each pair was placed in a similar cage and kept under the same conditions as described above for the development experiment. The number of egg clusters laid by each female was recorded over a period of approximately two months (some females died before the end of the experiment), and the interval between the laying of each cluster of eggs was calculated for each female. The total number of eggs laid by each female during her lifetime was not recorded because the experiment was terminated while the adults were still active, because it became too difficult and time consuming to find good-quality caper plants from late autumn (November) onwards, the season when they are very scarce.

We also assessed the effect of lack of mating on egg fertilization in experienced females by removing five females from the rearing system and keeping each of them separately, under the same conditions as above, without males. The percentage egg hatch was calculated for each egg cluster.

\section{Statistics}

Statistical analysis was done using JMP software, version 7.0.7 (SAS Inc.). The effects of temperature and day length on the intervals between egg laying were subjected to Two-Way ANOVA followed by a Tukey HSD test.

\section{RESULTS}

\section{Global and local (Israeli) distribution}

Members of the genus Stenozygum occur in the Palaearctic, Ethiopian, Oriental and Australian regions (Fig. 2). $\mathrm{CB}$ is recorded in the Middle East and eastern and subSaharan Africa (Derjanschi \& Péricart, 2005; Rider, 2006; Robertson, 2009, citations within), although the records for sub-saharan Africa should be regarded as uncertain (Linnavouri, 1975). CB is the northernmost distributed member of the genus; its range extends north to southern Turkey (Lodos et al., 1998). There is only one confirmed record of CB in southern Europe, on mainland Greece (Vidal, 1949).
It is worth mentioning that the genus Capparis occurs in tropical and subtropical regions worldwide (Jacobs, 1965; Willis, 1988) (Fig. 2) and different species of caper may be available for CB in different areas (see below).

In Israel, CB was recorded at various sites in the northern and central Mediterranean regions, as well as eastern semiarid regions in the Jordan Valley (Bodenheimer, 1930; Linnavouri, 1960; Kugler, 1985; Swirski et al., 2002). In the present study, CB was found on caper plants in almost all the Israeli locations surveyed (Fig. 1) in the northern and central parts, as well as the southern arid areas in the Negev Desert (most often on capers growing on rocky cliffs, as in the Wadi Qelt, Sde-Boker area and Ramon Crater). It was also frequently recorded in pine forests in all parts of the country, including the southernmost planted pine forests in the southern Judean Hills, i.e., the Lahav and Yatir Forests, where caper plants are common. Surprisingly, outside these two forests, caper plants and consequently also the bugs were very uncommon (see Discussion). CB was not recorded at high altitudes (above approximately $500 \mathrm{~m}$ ) on the Golan Heights and Mt. Hermon, although caper plants are common in these areas, at up to about $1200 \mathrm{~m}$ (Danin, 2010). In southern Turkey CB was also quite common on caper plants, although only up to an altitude of approximately $300 \mathrm{~m}$.

\section{Life history}

\section{Adult stage and sex ratio}

For a detailed morphological description of the adults see Derjanschi \& Péricart (2005). The colour is generally

TABLE 1. Body and hind tibia lengths of the nymphal and adult stages of Stenozygum coloratum.

\begin{tabular}{ccc}
\hline Body length $(\mathrm{mm})$ & Hind tibia length $(\mathrm{mm})$ & Development stage \\
\hline $0.98 \pm 0.06$ & $0.45 \pm 0.08$ & L1 \\
$1.71 \pm 0.11$ & $0.68 \pm 0.06$ & L2 \\
$2.90 \pm 0.75$ & $0.93 \pm 0.07$ & L3 \\
$3.98 \pm 0.13$ & $1.32 \pm 0.09$ & L4 \\
$5.67 \pm 0.17$ & $1.50 \pm 0.07$ & L5 \\
$6.02 \pm 0.12$ & $2.00 \pm 0.05$ & Males \\
$6.96 \pm 0.13$ & $2.40 \pm 0.07$ & Females \\
\hline
\end{tabular}




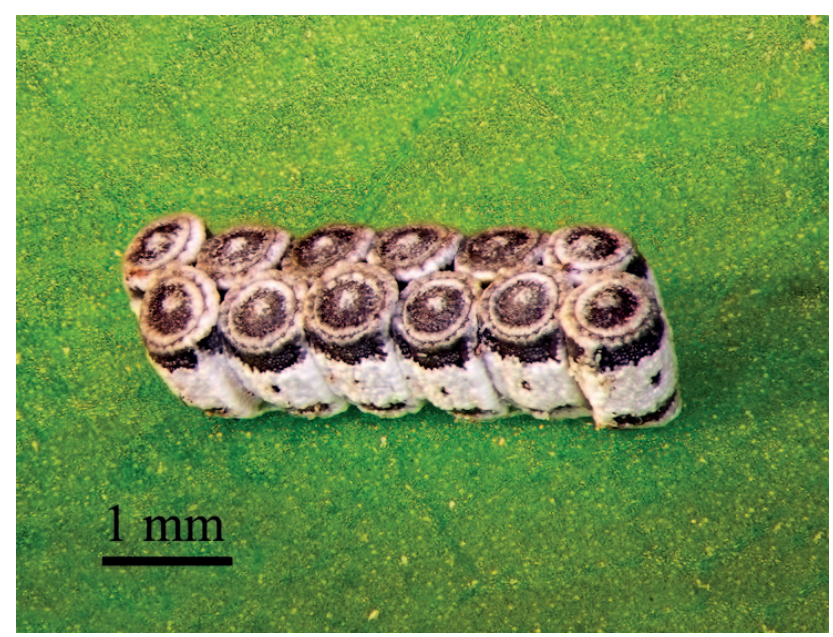

Fig. 4. A typical egg cluster of Stenozygum coloratum.

black with white and orange markings (Fig. 3). Females are similar in colour to males, but larger, at approximately $7 \mathrm{~mm}$ in length, compared with $6 \mathrm{~mm}$ for males (Table 1). Males and females were often observed together in large numbers, forming large aggregations on caper plants; up to several-hundred individuals were recorded on a single plant.

In the field, the sex ratio was approximately $1: 1$, with in a sample of 348 individuals collected at the end of August 2012 there were 38 males and 43 females at Gilboa, and 134 males and 133 females at Lahav. In the laboratory, the sex ratio of cohorts reared in the development experiments at $25^{\circ} \mathrm{C}$ was female-biased at approximately $1: 2$, with a total of 38 males and 70 females.

\section{The egg}

The eggs are barrel-shaped, $1.07 \pm 0.05 \mathrm{~mm}$ long and $0.64 \pm 0.07 \mathrm{~mm}$ wide. The dominant colour of the eggs is off-white, with a brown ring around the upper part, under the operculum. The operculum itself is brown (Fig. 4). An egg cluster usually contains 12 eggs in two six-egg rows (Fig. 4), although egg clusters of 10 to 13 eggs are also occasionally found. In the laboratory, and under certain

TABLE 2. Percentage mortality ( \pm SE) and duration of development of the different life stages of Stenozygum coloratum reared on Capparis zohary at $25^{\circ} \mathrm{C}$.

\begin{tabular}{cccc}
\hline Development stage & $\begin{array}{c}\text { Mean duration } \\
\text { (days) }\end{array}$ & $\begin{array}{c}\text { Range } \\
\text { (days) }\end{array}$ & $\begin{array}{c}\text { Mortality } \\
(\%)\end{array}$ \\
\hline egg & 6 & 6 & $9.61 \pm 2.71$ \\
L1 & 4 & 4 & $10.83 \pm 7.34$ \\
L2 & $5.38 \pm 0.09$ & $5-6$ & $8.56 \pm 8.05$ \\
L3 & $5.56 \pm 0.09$ & $5-7$ & $5.35 \pm 6.11$ \\
L4 & $7.11 \pm 0.11$ & $6-8$ & $0.83 \pm 2.64$ \\
L5 & $8.82 \pm 0.15$ & $7-10$ & $0.83 \pm 2.64$ \\
Pre-oviposition period & $7.30 \pm 0.48$ & $7-8$ & - \\
Total nymphal period & $30.87 \pm 0.19$ & $29-35$ & $26.41 \pm 5.37$ \\
Total development & $36.87 \pm 0.19$ & $35-41$ & $36.02 *$ \\
\hline
\end{tabular}

* Value is an estimate based on the sum of two separate sets of data - egg hatch and nymphal mortality, therefore, the standard deviation could not be calculated. conditions such as low temperature (about $20^{\circ} \mathrm{C}$ ) or lack of mating, an abnormal number of eggs is more common: 3 to 23 eggs in a single cluster; all usually infertile.

In the laboratory $9.6 \pm 2.7 \%$ of the eggs failed to hatch (55 out of 575 eggs from a total of 48 egg clusters, Fig. 5 ) and more than a third of the egg clusters (18 out of 48) contained at least one unhatched egg. These eggs were either undeveloped $(3.29 \pm 2.12 \%$ of the total number of eggs), or contained a fully developed dead nymph (6.31 $\pm 1.87 \%$ ), which probably died shortly prior to hatching, possibly because it was unable to push itself out through the operculum. Interestingly, $\mathrm{CB}$ is cannibalistic as individuals (adults and nymphs) were occasionally observed feeding on eggs inside the rearing cages, which may also have contributed to the recorded percentage egg mortality, but the frequency of this behaviour was not determined.

In the field, egg clusters were usually found on the upper surface, sometimes on the undersurface of caper leaves and, occasionally, also on the stems. In the laboratory, however, a substantial percentage, sometimes the majority, of the egg clusters were laid on other surfaces than the plant, usually in somewhat hidden locations, as under the paper sheet placed on the bottom of the cage and on the back of the cardboard sheet that was placed inside the cage - i.e., facing the inner, shaded side of the cage wall. Because of its frequency, this behaviour was thought to be deliberate and possibly a means of concealing egg clusters. Nonetheless, attempts to find egg clusters in the field that were not laid on plants generally failed. This may have been due to the difficulty of locating these egg clusters, either because

TABLE 3. Hosts of Stenozygum coloratum belonging to the Capparaceae recorded in particular localities and areas.*

\begin{tabular}{lccc}
\hline Area & Localities & Host species & Source** $^{*}$ \\
\hline \multirow{3}{*}{ Israel } & Bet-Shean valley & Capparis sicula & Present study \\
\cline { 2 - 4 } & $\begin{array}{c}\text { Northern and central } \\
\text { parts }\end{array}$ & $\begin{array}{c}\text { Capparis } \\
\text { zoharyi }\end{array}$ & Present study \\
\cline { 2 - 4 } & $\begin{array}{c}\text { All the country (south to } \\
\text { central Negev mountains }\end{array}$ & $\begin{array}{c}\text { Capparis } \\
\text { aegyptia }\end{array}$ & Present study \\
\cline { 2 - 4 } & $\begin{array}{c}\text { Northern and central } \\
\text { parts }\end{array}$ & $\begin{array}{c}\text { Capparis } \\
\text { spinosa** }\end{array}$ & $\begin{array}{c}\text { Linnavuori, } \\
1960\end{array}$ \\
\hline \multirow{2}{*}{$\begin{array}{c}\text { Rest of } \\
\text { East }\end{array}$} & Saudi Arabia & $\begin{array}{c}\text { Maerua } \\
\text { crassifolia }\end{array}$ & $\begin{array}{c}\text { Linnavuori et } \\
\text { al., 1986 }\end{array}$ \\
\cline { 2 - 4 } & All areas & $\begin{array}{c}\text { Capparis spp. } \\
\text { Capparis } \\
\text { spinosa }\end{array}$ & $\begin{array}{c}\text { Derjanschi \& } \\
\text { Péricart, 2005 } \\
\text { (incl. citations) }\end{array}$ \\
\hline \multirow{2}{*}{ Africa } & East & Capparis spp. & $\begin{array}{c}\text { Derjanschi \& } \\
\text { Péricart, 2005 } \\
\text { (incl. citations) }\end{array}$ \\
\cline { 2 - 4 } & Sub-Saharan & Unknown & $\begin{array}{c}\text { Robertson, } \\
\text { 2009 }\end{array}$ \\
\hline
\end{tabular}

* Only those hosts that are likely to be suitable for reproduction are included, i.e. belonging to the Capparaceae. The results of the present study indicated that species of plants belonging to other families on which $\mathrm{CB}$ was found were not suitable for reproduction, and they are summarized separately in Appendix 1.

** According to the reclassification of Innocencio et al. (2006) this Capparis spinosa is not found in Israel, thus this reference is likely to be for another species of Capparis. 


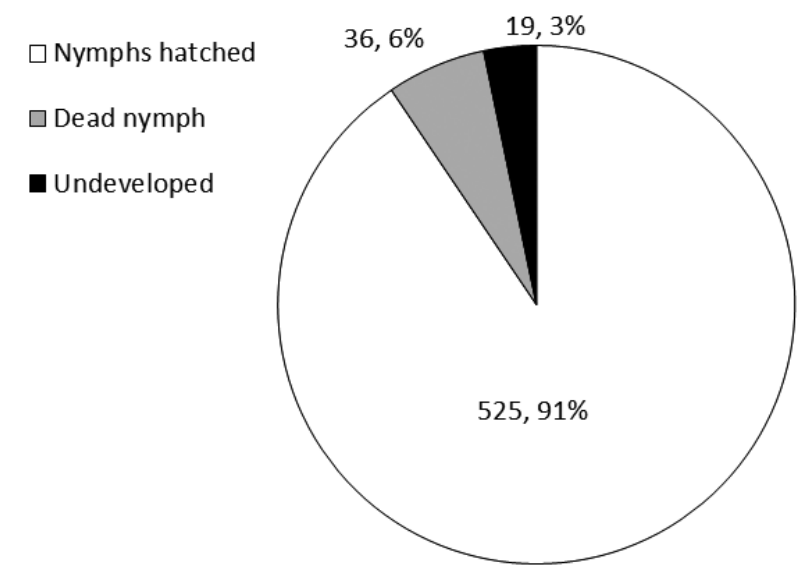

Fig. 5. Percentage egg hatch and mortality (total number, percentage) ( $n=575$ eggs from 48 egg clusters) of Stenozygum coloratum recorded in the laboratory. Causes of mortality and percentages were checked by dissecting the unhatched eggs and determining the number of undeveloped eggs and the number that contained a dead nymph.

of their scarcity, or their tendency to become detached from the substrate after the nymphs hatch. However, on a few occasions egg clusters were found attached to rocky surfaces or small rocks near or under the host plant.

Nymphal development

The five nymphal stages have a mostly black head and thorax, with some white and orange patterning in the $3^{\text {rd }}$ to $5^{\text {th }}$ stages (Fig. 3). The abdomen is predominantly orange, with four transverse black stripes, and its edges have black and white stripes. Dimensions are given in Table 1. Table 2 presents data on development of CB individuals fed on Capparis zoharyi at $25^{\circ} \mathrm{C}$. After hatching, the $1^{\text {st }}$ instar nymphs congregated on the egg cluster; two days later they fed for a few hours and then ceased moving; and after two more days moulted for the first time. The nymphs needed to either feed or drink water to reach the second instar. Total larval development lasted 29-35 days, and total development from egg to adult thus took 35-41 days (Table 2). Nymphal stages and adults fed on all parts of the plant, i.e., stems, leaves, flower buds and fruits; the nymphs completed their development feeding on any of these plant parts, although both adults and nymphs seemed to prefer fruit over leaves and stems. They tended to congregate on fruit, when available, as observed in the laboratory cages and in the field. Both adults and nymphs were often observed

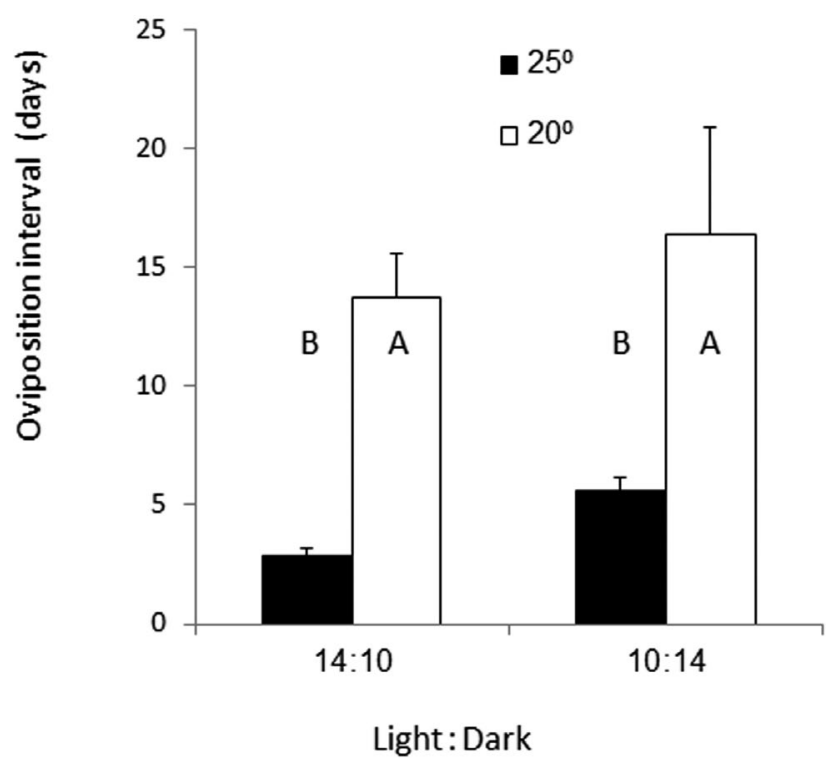

Fig. 6. Effects of temperature and day length on the interval between laying clusters of eggs (days $\pm \mathrm{SE}$ ) recorded for Stenozygum coloratum females. Treatment values marked with different letters are significantly different (Two-way ANOVA followed by Tukey's HSD test, $\mathrm{p}<0.05$ ).

feeding also on stems of severely damaged or completely defoliated plants, and it seemed that CB nymphs can complete their development on these plants.

About a quarter $(26.4 \pm 5.4 \%)$ of the individuals died in the nymphal stage (Table 2); some of them, especially the younger stages, may have been injured during handling, e.g., replenishing food, etc. Thus, in the laboratory, about one out of three eggs failed to reach maturity.

\section{Host range}

$\mathrm{CB}$ is frequently reported on C. spinosa L. (Capparaceae) and other unidentified congeners in the Middle East and north-eastern Africa (Table 3). It is also recorded on Maerua crassifolia (Capparacaeae) on the Arabian Peninsula (Linnavuori, 1986). No data are available on CB hosts in sub-Saharan Africa. In Israel, we found all development stages of $\mathrm{CB}$ on $C$. zoharyi in the central and northern parts of the country (Table 3), on C. aegyptia in the central Negev Desert (Sde Boker area and Ramon Crater) and also on $C$. sicula in the Beit-She'an Valley (see Fig. 1 for geographical locations). Laboratory trials clearly indicated that $\mathrm{CB}$ is able to develop successfully on all three caper species (data not shown).

TABLE 4. Percentage survival $(\% \pm \mathrm{SE})$ of Stenozygum coloratum nymphs recorded in the various feeding regimes. Data for each treatment are based on three replicates, each of a single cohort of 11-12 individuals.

\begin{tabular}{lcccccc}
\hline Treatment & L1 & L2 & L3 & L4 & L5 & Total \\
\hline Solanum lycopersicum & $97.2 \pm 3.4$ & $0.0 \pm 0.0$ & - & - & - & $0.0 \pm 0.0$ \\
Capsicum annuum & $94.4 \pm 6.8$ & $0.0 \pm 0.0$ & - & - & - & $0.0 \pm 0.0$ \\
Persea americana & $100.0 \pm 0.0$ & $0.0 \pm 0.0$ & - & - & - & $0.0 \pm 0.0$ \\
Citrus sp. & $97.2 \pm 3.4$ & $17.9 \pm 11.3$ & $0.0 \pm 0.0$ & - & - & $0.0 \pm 0.0$ \\
Ficus carica & $100.0 \pm 0.0$ & $69.4 \pm 3.4$ & $80.1 \pm 4.6$ & $69.8 \pm 10.3$ & $72.2 \pm 18.0$ & $27.8 \pm 6.8$ \\
Capparis zoharyi & $97.2 \pm 3.4$ & $88.1 \pm 3.9$ & $97.0 \pm 3.7$ & $93.0 \pm 4.3$ & $95.8 \pm 5.1$ & $77.8 \pm 14.8$ \\
Water only & $100.0 \pm 0.0$ & $0.0 \pm 0.0$ & - & - & - & $0.0 \pm 0.0$ \\
\hline
\end{tabular}


TABLE 5. Mean duration of development (days \pm SE) and maximum nymphal period (days) of Stenozygum coloratum nymphs recorded in the various feeding regimes. Data from each treatment are based on three replicates, each of a single cohort of 11-12 individuals. Mean duration of development of each nymphal stage was based only on individuals that survived to the next developmental stage. Duration of development from L1 to adulthood was based on data for individuals that reached the adult stage, and the maximum nymphal period was based on data for all the nymphs, regardless of the development stage they reached.

\begin{tabular}{|c|c|c|c|c|c|c|c|}
\hline Treatment & $\mathrm{L} 1$ & $\mathrm{~L} 2$ & L3 & L4 & L5 & $\begin{array}{l}\text { Development to } \\
\text { adulthood }\end{array}$ & $\begin{array}{l}\text { Max. nymphal } \\
\text { period }\end{array}$ \\
\hline Solanum lycopersicum & $4.0 \pm 0.0$ & - & - & - & - & - & 13 \\
\hline Capsicum annuum & $4.0 \pm 0.0$ & - & - & - & - & - & 8 \\
\hline Persea americana & $4.0 \pm 0.0$ & - & - & - & - & - & 35 \\
\hline Citrus sp. & $4.0 \pm 0.0$ & $23.9 \pm 3.7$ & - & - & - & - & 86 \\
\hline Ficus carica & $4.0 \pm 0.0$ & $14.5 \pm 0.4$ & $16.5 \pm 1.2$ & $19.5 \pm 2.2$ & $18.9 \pm 1.1$ & $73.7 \pm 3.8$ & 91 \\
\hline Capparis zoharyi & $4.0 \pm 0.0$ & $5.3 \pm 0.1$ & $6.6 \pm 0.1$ & $7.0 \pm 0.1$ & $8.6 \pm 0.1$ & $31.7 \pm 0.3$ & 34 \\
\hline Water only & $4.0 \pm 0.0$ & - & - & - & - & - & 7 \\
\hline
\end{tabular}

$\mathrm{CB}$ was also recorded on a wide array of annual and perennial crops belonging to other botanical families - 11 families in total, summarized in Appendix 1. Many of these plants, such as avocado, Citrus and persimmon, are not native to the distribution range of $\mathrm{CB}$ and laboratory development trials with five of the plants on the above list revealed that most are not a suitable source of food for complete development (Table 5), although nymphs were able to survive for prolonged periods, e.g., up to 3 months on Citrus and reached the $2^{\text {nd }}$ or $3^{\text {rd }}$ instar on Solanum lycopersicum, Capsicum annuum, Persea americana and Citrus sp.. Surprisingly, common fig, Ficus carica, was suitable for complete development, although mortality rates were high (Table 4) and development took much longer than when fed on capers (Table 5). However, adults reared on fig did not reproduce, unless their diet was replaced with caper. Nymphs that were given water alone moulted to the second instar without feeding, but died shortly after the first moult.

Effects of temperature, day length and mating on reproduction

Mating usually took place on a plant. Females needed to mate prior to laying each egg cluster to ensure egg fertilization. When females were prevented from mating after laying an egg cluster, about half $(48.3 \pm 7 \%, n=5$ egg clusters) of the eggs of the next cluster were infertile and subsequent clusters contained only infertile eggs.

At $25^{\circ} \mathrm{C}$ and under a long-day regime (14L : 10D) the females began to oviposit about 1 week $(7.3 \pm 0.5$ days $)$ after the last moult (Table 2). Thus, a complete generation lasted approximately 42-48 days. Under the above conditions females laid an average of one egg cluster (12 eggs) approximately every 3 days, i.e., an oviposition interval of $2.8 \pm 0.4$ days (Fig. 6). The females continued to lay eggs at temperatures down to $20^{\circ} \mathrm{C}$ but when kept at a constant temperature of $19^{\circ} \mathrm{C}$ or lower, they stopped reproducing almost immediately and mostly remained inactive on the cage walls, feeding on plants only occasionally. There were significant differences in the oviposition intervals of females kept at different temperatures and day-lengths (two-way ANOVA, $\mathrm{F}=67.5$, df =3,36, $p<0.0001$; Fig. 6). Significant differences were recorded between groups kept at different temperatures, whereas the differences between groups kept at different day lengths but similar temperatures were small and insignificant (Tukey HSD test; Fig. 6). At $20^{\circ} \mathrm{C}$ under a short-day regime of $10 \mathrm{~L}$ : $14 \mathrm{D}$ egg laying decreased to one egg cluster every 16 days (16.3 \pm 4.5; Fig. 6). A short-day period, at either 25 or $20^{\circ} \mathrm{C}$, did not promote hibernation or terminate reproductive activity. In fact, as long as temperatures were kept at or above $20^{\circ} \mathrm{C}$, the adults continued to mate and reproduce, regardless of day length.

\section{DISCUSSION}

Until the present study, CB was rarely mentioned in scientific literature, probably because of its minor economic importance. Its potential role as a summer host of OP (Mizrachi, 2006), a common natural enemy of PPM, drew our attention to this bug and stimulated us to shed light on several fundamental aspects of its natural history. We attempted to present a broad picture of its biology, rather than focusing on a single aspect. However, most of the features studied, such as distribution, host range, egg development and mortality, fecundity and the temperature threshold for reproductive activity, were chosen because they provide a better understanding of the spatial and temporal occurrence of $\mathrm{CB}$ at various locations and in different habitats, and their relevance to the occurrence and biocontrol using OP. In addition, as CB occurs in agricultural crops, this stimulated us to explore its ability to develop on these plants. This knowledge is likely to contribute to a better assessment of the risks involved in establishing large populations of this bug for augmenting OP populations.

$\mathrm{CB}$ is found in east and central sub-Saharan Africa and the Middle East, mostly in arid and semi-arid areas, and has a more northerly distribution than its congeners. The distribution of CB in Israel indicates that it is found at almost every location where there are suitable hosts, e.g., caper plants, and is not restricted to any particular habitat. The fact that $\mathrm{CB}$ is not recorded in the coldest regions of the area studied, i.e., the Golan Heights, above approximately $500 \mathrm{~m}$ above sea level, and above $300 \mathrm{~m}$ a.s.1 in southern Turkey, whereas its host plants are recorded at higher altitudes in both areas, indicate that this bug's distribution is limited by low temperature. This sensitivity to low temperatures is further confirmed by laboratory exper- 
iments that $\mathrm{CB}$ ceases reproducing at temperatures below $20^{\circ} \mathrm{C}$; this is a higher temperature threshold than that of other pentatomids, such as Nezara viridula L., 1758 (Todd, 1989) and Eurydema rugosa Motschulsky, 1861 (IkedaKikue \& Numata, 1992). This supports the notion that CB originated from more southerly, warmer areas, most likely in Africa, and later spread northwards into the Middle East. The tropical and subtropical distribution of the genus Capparis, of which some species serve as primary hosts of $\mathrm{CB}$, further supports this notion of an origin in a warmer region.

Caper plants are quite common in Israel and are recorded in most areas and habitats, where several species, mainly C. zoharyi, C. aegyptia and C. sicula (Danin, 2010) occur. $\mathrm{CB}$ reproduces on all three species, indicating that other Capparis spp. are also likely to be suitable host plants. This bug is also frequently recorded on C. spinosa in the Middle East and north-eastern Africa (Linnavuori, 1960, 1975, 1986; Kugler, 1985; Derjanschi \& Péricart, 2005). Nonetheless, the classification of members of this subsection of Capparis was recently changed (Inocencio et al., 2006). Consequently, the distribution of $C$. spinosa, which previously included almost all the Mediterranean basin, was substantially reduced to several areas in southern Europe, where it is likely that $\mathrm{CB}$ does not occur. As a result of this reclassification it is unclear whether $C$. spinosa is actually used by this bug.

C. zoharyi and other closely related congeners, on which this bug was recorded in the present study, belong to the old-world subsection of Capparis. They are found mainly from central Asia to the western Mediterranean area and only partially overlap the northern distribution of CB (for a more detailed data on the distribution of each species see Inocencio et al., 2006). Therefore, other host species must be utilized, at least in the southern part of its distribution, e.g., sub-Saharan Africa, where the latter species do not occur. Members of the genus Capparis are recorded worldwide and it is likely that other caper species are used as hosts, at least in the southern part of CB's distribution.

Most phytophagous species of pentatomid are polyphagous (Derjanschi \& Henry, 2006; Rider, 2006; Henry, 2009). Switching between cultivated and wild host plants is common, although local populations of many species might have relatively narrow host ranges (Panizzi, 1997). Bodenheimer (1930, 1951) and Avidov (1961) record egg clusters and nymphs of $\mathrm{CB}$ on citrus, avocado and a few other agricultural plants, and conclude that $\mathrm{CB}$ is also polyphagous. Our laboratory experiments confirmed that $\mathrm{CB}$ adults and nymphs are able to survive for prolonged periods on other plant species, apart from those belonging to the Capparacea, and can complete development on at least one of them, i.e., common fig. It is not unlikely that other species of plants, which were not examined in the present study, are suitable or partially suitable for nymphal development. However, adults reared on fig were unable to reproduce on this plant; for egg laying females need to feed on caper. This means that CB cannot survive on fig alone and switching back to caper is required for population survival. Therefore, our findings indicate that $\mathrm{CB}$ is ol- igophagous, because it can reproduce only on caper plants, and possibly other genera belonging to the Capparaceae. The apparent specialization on capers is also indicated by the fact that unlike many other pentatomid species, which require fruit or seed to complete their development, (e.g. N. viridula Slansky \& Panizzi, 1987), CB is not restricted to the reproductive parts of its host plant and its nymphs are able to develop on all plant organs. The above findings may account for CB's typical tendency to remain on caper plants, even when other plant species are available nearby. Prolonged survival of nymphs and adults on other species of plants indicates that these plants may provide a temporary refuge for $\mathrm{CB}$ in the absence of its preferred host, caper plants. In fact, in Israel individual CBs are often recorded at the periphery of avocado, mango, citrus and persimmon orchards, and there is evidence of short-distance migration of individuals from dried-up caper plants to nearby citrus or avocado trees (present authors' unpublished data). Host switching most likely occurs when capers become scarce or unavailable, or when their physiological state makes them unsuitable hosts, which is mainly in late summer (Swirski et al., 2002). Regarding the distinction between host plants (i.e. those suitable for completing development), overwintering or shelter plants, feeding plants and casual plants mentioned earlier (Burckhardt at al., 2014) we propose a further distinction between hosts suitable for nymphal development and hosts suitable for reproduction. This distinction is required, at least in the case of $\mathrm{CB}$, since it was shown that although common fig (and possibly other plants) was suitable for development, it was not suitable for initiating reproductive activity. Accordingly, we consider restricting the use of "host plants" to plants on which not only nymphal development to adulthood is achieved, but also reproductive activity is possible (i.e. mating, oocyte maturation and oviposition).

At $25^{\circ} \mathrm{C}$ CB completes a full generation in approximately 45 days. Similar development rates are recorded for other pentatomid species, e.g., Nezara viridula (citations within Todd, 1989), Glyphepomis spinosa Campos \& Grazia, 1998 (Alves et al., 2012) and Halyomorpha halys Stål, 1855 (Nielsen et al., 2008). Laboratory experiments reveal that temperature had a strong effect on the termination of reproductive activity because when the temperature fell below $20^{\circ} \mathrm{C}$ reproductive activity ceased almost immediately, whereas day length did not have a significant effect. The small decrease in egg laying recorded in short-day regimes may have resulted from a reduction in food intake as a result of the shorter daily activity period, although this needs to be confirmed.

The adult sex ratio of laboratory reared CB was female biased $(1 \hat{\sigma}: 2$ + $)$ and differed from that recorded in the field $(1: 1)$. As in other species of this group, $\mathrm{CB}$ has a $\mathrm{XY} / \mathrm{XX}$ sex chromosome-determining system (Rebagliati et al., 2005) and, therefore, a 1:1 ratio is expected. A female-biased sex ratio is also recorded for other pentatomids such as Picromerus bidens L., 1758 (Mahdian et al., 2008) and Murgantia histrionica Hahn, 1834 (Streams \& Pimentel, 1963), with an apparent temperature effect in the 
case of the former. Different sex ratios might be attributed to differing male and female mortality rates in the nymphal stages (Streams, 1962), which might account for the biased sex ratio recorded in the laboratory in the present study.

A marked decline in the percentage of fertilized eggs was recorded in egg clusters laid by $\mathrm{CB}$ females that were prevented from mating. We suspect that $\mathrm{CB}$ females need to mate frequently, as reported for other species (Wang \& Millar, 1997; Cônsoli et al., 2010; Silva et al., 2012), and this might account for why male and female adults tend to stay in close proximity to one another and form large aggregations on plants.

In the field, egg clusters of CB were found mainly on the upper surface of caper leaves However, in the laboratory many, and sometimes most, of the egg clusters were laid in other, often hidden locations. Theoretically, this could also be explained simply by the caged females spending more time on other surfaces than that of the plant. Yet frequent observations indicated that caged $\mathrm{CB}$ individuals spend most of the time on plants, therefore, the apparent concealment of eggs may in fact be intentional. The laying of eggs on surfaces other than a plant is also occasionally recorded in the field. However, in the laboratory individuals were confined to a relatively small space, in which moving off a plant is much faster and easier. Thus, the laying of eggs on other surfaces might be much less common in the field than in the laboratory. The laying of a substantial proportion of the egg clusters in sheltered locations, or on surfaces other than a host plant, is also recorded by Dzerefos et al. (2009) and Wang \& Millar (1997) for captive Encosternum delegorguei Spinola, 1852 (Hemiptera: Tessaratomidae) and Thyanta pallidovirens Stål, 1859 (Hemiptea: Pentatomidae). In both cases this behaviour was only briefly described and not considered further, because egg laying was not the focus of these studies. In the field, however, locating concealed egg clusters is difficult and it is likely that this behaviour has been overlooked in other heteropteran species. The difficulty of finding concealed egg clusters in the field indicates a greater effort is needed to find them if we are to obtain a clearer picture of this behavior and its prevalence. Egg concealment might serve to reduce egg predation, parasitism, or even cannibalism (see below). This may also account for the fact that occasionally no egg clusters are recorded on heavily infested plants on which all nymphal stages are present (data about to be published). The egg cannibalism recorded in the present study may have contributed to the recorded egg mortality, although it is not known how often it occurs and whether it occurs in the field. Cannibalism is recorded in other heteropteran species, both predatory and herbivorous, which belong to various families (for examples see Pajunen \& Pajunen, 1991; Anderson \& Solbreack 1992; Pires et al., 2011; Weinstein, 2014).

During our field surveys it was noticed that pine forests were among the preferred habitats of caper plants in Israel. However, almost all Israeli pine forests were planted during the last 150 years (Liphschitz \& Biger, 2004) and natural pine stands account for less than $1 \%$ of the pine forests in Israel. Surprisingly, the abundance of capers in planted pine forests is sometimes much higher than in surrounding areas. We hypothesize that this is the result of a tendency of capers to colonize disturbed areas, in which competition with other plants is temporarily reduced (Danin, 2010). In pine forests, specifically, we suspect that various kinds of anthropogenic disturbances, associated with either site preparation prior to pine planting, road construction, or occasional unintentional fires, may have supported and accelerated caper establishment. In this habitat the caper plants commonly grow under or very close to pine trees and do not seem to be negatively affected by their proximity; thus CB was frequently recorded in large numbers in these forests. It is likely that the recent establishment of caper plants in newly planted pine forests, which was probably followed by an increase in CB abundance, may have created a new niche for OP populations. Thus, encouraging caper establishment in areas where it is relatively uncommon may help to increase OP populations, which may, in turn, promote natural control of PPM.

In conclusion, in the present study we shed light on some biological aspects of $\mathrm{CB}$. The data we obtained increases our understanding of the switch of this oligophagous bug to cultivated crops, and provide a basis for further study of the tritrophic relationship between caper plants, CB and its egg parasitoids, with particular interest in OP. The results of the present study, together with newly collected field data that are about to be published, may help to evaluate the potential importance of CB and caper plants in the conservation of the population of the latter egg parasitoid, as part of managing PPM.

ACKNOWLEDGEMENTS. We would like to thank A. Nir for assistance in locating the literature on CB. We are also grateful to A. Danin for helping with information on the various Israeli Capparis species. We appreciate the constructive suggestions and modifications suggested by two anonymous reviewers of a previous version of this manuscript. This study was funded by the Keren Kayemeth LeIsrael/the Jewish National Fund (Project 1311619-13). This paper is part of the PhD dissertation of S. Samra at the Hebrew University of Jerusalem.

\section{REFERENCES}

Ahmad I. \& Khan N. 1983: A revision of the genus Stenozygum Fieber (Pentatomidae: Strachini) from the Oriental and Australian regions, with reference to zoogeography and phylogeny. - Aust. J. Zool. 31: 581-605.

Alves T.M., Barrigossi J.A.F. \& Quintela E.D. 2012: Life cycle of Glyphepomis spinosa Campos and Grazia (Hemiptera: Pentatomidae): a new pest of rice in Brazil. - Neotrop. Entomol. 41: 437-441.

Anderson D.B. \& Solbreck C. 1992: Who eats whom? Complex interactions between an egg parasitoid and its cannibalistic host. - Oikos 63: 459-464.

Avidov P. 1961: Pests of the Cultivated Plants of Israel. Magness Press, The Hebrew University, Jerusalem, 546 pp. [in Hebrew].

Batтisti A. 1988: Host-plant relationships and population dynamics of the pine processionary caterpillar Thaumetopoea pityocampa (Denis \& Schiffermüller). - J. Appl. Entomol. 105: 393-402. 
BAtтisti A. 1989: Field studies on the behaviour of two egg parasitoids of the pine processionary moth (Thaumetopoea pityocampa). - Entomophaga 34: 29-38.

BodenheImer F.S. 1930: Die Schaedlingsfauna Palaestinas. P. Parley, Berlin, 438 pp.

BodenHeIMER F.S. 1951: Citrus Entomology in the Middle East with Special References to Egypt, Iran, Iraq, Palestine, Syria, Turkey, Dr. W. Junk, The Hague, 663 pp.

Burckhardt D., Quvrard D., QueIroz D. \& Percy D. 2014: Psyllid host-plants (Hemiptera: Psylloidea): resolving a semantic problem. - Fla Entomol. 97: 242-246.

Carapezza A. 2011: Stenozygum (s. str.) jordiribesi sp. nov., a new species of Strachiini from the island of Socotra (Hemiptera: Heteroptera: Pentatomidae: Pentatominae). — Heteropt. Rev. Entomol. 11: 201-207.

CARUS S. 2004: Impact of defoliation by the pine processionary moth (Thaumetopoea pityocampa) on radial, height and volume growth of calabrian pine (Pinus brutia) trees in Turkey. - Phytoparasitica 32: 459-469.

Cônsoli F.L., Parra J.R.P. \& Zucchi R.A. 2010: Egg Parasitoids in Agroecosystems with Emphasis on Trichogramma. Springer, Dordrecht, $482 \mathrm{pp}$.

DANIN A. 2010: Capparis in the East Mediterranean countries. Flora Mediter. 20: 179-185.

Derjanschi V. \& Péricart J. 2005: Hémiptères Pentatomoidea Euro-méditerranéens. Vol. 1. Fédération française des sociétés de sciences naturelles, Paris, pp. 408-411.

Dzerefos C.M., Witkowski E.T.F. \& Toms R. 2009: Life history traits of the edible stinkbug, Encosternum delegorguei (Hem., Tessaratomidae), a traditional food in southern Africa. $-J$. Appl. Entomol. 133: 749-759.

GHAURI M.S.K. 1972: Notes on the Hemiptera from Pakistan and adjoining areas. - J. Nat. Hist. 6: 279-288.

Halperin J. 1990: Life history of Thaumetopoea spp. (Lep., Thaumetopoeidae) in Israel. - J. Appl. Entomol. 110: 1-6.

Henry T.J. 2009: Biodiversity of Heteroptera. In Foottit R.G. \& Adler P.H. (eds): Insect Biodiversity: Science and Society. 1st ed. Wiley-Blackwell, Oxford, UK, pp. 223-263.

IKedA-Kikue K. \& Numata H. 1992: Effects of diet, photoperiod and temperature on the postdiapause reproduction in the cabbage bug, Eurydema rugosa. - Entomol. Exp. Appl. 64: $31-36$.

Inocencio C., Rivera D., Concepción Obón M., Alcaraz F. \& BARREÑa J.A. 2006: A systematic revision of Capparis section capparis (Capparaceae). - Ann. Missouri Bot. Gard. 93: 122-149.

JACOBS M. 1965: The genus Capparis (Capparaceae) from the Indus to the Pacific. - Blumea: J. Plant Taxon. Plant Geogr. 12: $385-541$.

Jacquet J.S., Bosc A., O’Grady A.P. \& Jactel H. 2013: Pine growth response to processionary moth defoliation across a 40year chronosequence. - For. Ecol. Manag. 293: 29-38.

Kanat M., Alma M.H. \& SivriKaya F. 2005: Effect of defoliation by Thaumetopoea pityocampa (Den. \& Schiff.) (Lepidoptera: Thaumetopoeidae) on annual diameter increment of Pinus brutia Ten. in Turkey. - Ann. For. Sci. 62: 91-94.

Kitт J. \& Schmidt G.H. 1993: Parasitism of egg-batches of the pine processionary moth Thaumetopoea wilkinsoni Tams (Lep., Thaumetopoeidae) in the mountains of Lahav (Israel). - J. Appl. Entomol. 115: 484-498.

Kugler J. 1985: Plants and Animals of the Land of Israel - Insects. Ministry of Defense, Tel-Aviv, $122 \mathrm{pp}$.

Linnavuori R.E. 1960: Hemiptera of Israel. I. - Ann. Zool. Soc. Zool. Bot. Fenn. Vanamo 22: 1-108.
LINNAVUORI R.E. 1975: Hemiptera of the Sudan, with remarks on some species of the adjacent countries. 5. Pentatomidae. Bol. Soc. Portug. Ciênc. Nat. 15: 5-128.

LinNAVUORI R.E. 1986: Heteroptera of Saudi Arabia. — Fauna Saudi Arab. 8: 31-197.

Liphschitz N. \& Biger G. 2004: Green Dress for a Country. Ariel, Jerusalem, $328 \mathrm{pp}$.

Lodos N., Önder F., Pehlivan E., Atalay R., Erkin E., Karsavuran Y., Tezcan S. \& Aksoy S. 1998: Faunistic Studies on Pentatomoidea: (Plataspidae, Acanthosomatidae, Cydnidae, Scutelleridae, Pentatomidae) of Western Black Sea, Central Anatolia and Mediterranean Regions of Turkey. Department of Plant Protection, Faculty of Agriculture, University of Ege, $85 \mathrm{pp}$.

Mahdian K., Tirry L. \& De Clerce P. 2008: Development of the predatory pentatomid Picromerus bidens (L.) at various constant temperatures. - Belg. J. Zool. 138: 135-139.

Mizrachi A. 2006: Seasonal Activity and Aspects in Reproductive Behavior of Ooencyrtus pityocampae (Hymenoptera: Encyrtidae), an Egg Parasitoid of Thaumetopoea wilkinsoni (Lepidoptera: Notodontidae). MSc, Hebrew University, Jerusalem, 79 pp. [in Hebrew, English abstr.].

Nielsen A.L., Hamilton G.C. \& Matadha D. 2008: Developmental rate estimation and life table analysis for Halyomorpha halys (Hemiptera: Pentatomidae). - Environ. Entomol. 37: 348-355.

Pajunen V.I. \& Pajunen I. 1991: Oviposition and egg cannibalism in rock-pool corixids (Hemiptera: Corixidae). — Oikos 60: 83-90.

PANizZI A.R. 1987: Nutritional ecology of seed-sucking insects of soybean and their management. - Mem. Inst. Oswaldo Cruz 82: 161-175.

Panizzi A.R. 1997: Wild hosts of pentatomids: ecological significance and role in their pest status on crops. - Annu. Rev. Entomol. 42: 99-122.

Panizzi A.R., McPherson J.E., James D.G., Javahery M. \& MCPHERSOn R.M. 2000: Stink bugs (Pentatomidae). In Schaefer C.W. \& Panizzi A.R. (eds): Heteroptera of Economic Importance. CRC Press, Boca Raton, FL, pp. 421-474.

Pires E.M., Zanuncio J.C. \& Serrão J.E. 2011: Cannibalism of Brontocoris tabidus and Podisus nigrispinus during periods of pre-release without food or fed with Eucalyptus cloeziana plants. - Phytoparasitica 39: 27-34.

Rebagliati P.J., Mola L.M., Papeschi A.G. \& Grazia J. 2005: Cytogenetic studies in Pentatomidae (Heteroptera): A review. —J. Zool. Syst. Evol. Res. 43: 199-213.

Rider D. 2006: Family Pentatomidae Leach, 1815. In Aukema B. \& Rieger C. (eds): Catalogue of the Heteroptera of the Palaearctic Region. Vol 5. Pentatomorpha II. The Netherlands Entomological Society, Amsterdam, pp. 233-402.

Rider D. 2013: Pentatomidae Home Page [Online]. North Dakota State University. Available: http://www.ndsu.nodak.edu/ ndsu/rider/Pentatomoidea/acknowledgments.htm [Accessed 6 May 2013].

Robertson I.A.D. 2009: The Pentatomoidea (Hemiptera: Heteroptera) of Sub-Saharan Africa: A Database [Online]. [s.n.]. Available: http://www.repository.naturalis.nl/document/228798 [Accessed 30 Jan 2014].

Schaefer C.W. \& Panizzi A.R. 2000: Heteroptera of Economic Importance. CRC Press, Boca Raton, FL, pp. 5-6.

Schmidt H., Mirchev P. \& Tsankov G. 1997: The egg parasitoids of Thaumetopoea pityocampa in the Atlas mountains near Marrakech (Morocco). - Phytoparasitica 25: 275-281.

Schmidt G.H., Tanzen E. \& Bellin S. 1999: Structure of eggbatches of Thaumetopoea pityocampa (Den. and Schiff.) (Lep., 
Thaumetopoeidae), egg parasitoids and rate of egg parasitism on the Iberian Peninsula. — J. Appl. Entomol. 123: 449-458.

Silva C.C.A., Laumann R.A., Ferreira J.B.C., Moraes M.C.B., Borges M. \& CoKL A. 2012: Reproductive biology, mating behavior, and vibratory communication of the brown-winged stink bug, Edessa meditabunda (Fabr.) (Heteroptera: Pentatomidae). - Psyche (Stuttg.) 2012: 1-9.

Slansky F. JR. \& Panizzi A.R. 1987: Nutritional ecology of seedsucking insects. In Slansky F. Jr. \& Rodriguez G.J. (eds): $N u$ tritional Ecology of Insects, Mites, Spiders and Related Invertebrates. Wiley, New York, pp. 283-319.

Streams F.A. 1962: Studies on the Life History and Sex Ratio of the Harlequin Bug, Murgantia histrionica (Hahn), with Reference to the Significance of the Sex Ratio. Ph.D. Thesis, Cornell University, Ithaca, NY, $107 \mathrm{pp}$.

Streams F.A. \& Pimentel D. 1963: Studies on the sex ratio of the harlequin bug, Murgantia histrionica (Hemiptera: Pentatomidae). - Ann. Entomol. Soc. Am. 56: 712-716.

Swirski E., Wysoki M. \& Izhar Y. 2002: Subtropical Fruits Pests in Israel. Fruit board of Israel, Tel-Aviv, 284 pp. [in Hebrew, English abstr.].

Tamburini G., Marini L., Hellrigl K., Salvadori C. \& Battist A. 2013: Effects of climate and density-dependent factors on population dynamics of the pine processionary moth in the Southern Alps. - Clim. Change 121: 701-712.

TodD J.W. 1989: Ecology and behavior of Nezara viridula. Annu. Rev. Entomol. 34: 273-292.

Tsankov G. 1990: Egg parasitoids of the pine processionary moth, Thaumetopoea pityocampa (Den. \& Schiff.) (Lep., Thaumetopeidae) in Bulgaria: Species, importance, biology and behaviour. - J. Appl. Entomol. 110: 7-13.

VIDAL J. 1949: Hémiptères de l'Afrique du Nord et des pays circum-méditerranéens. Institut scientifique chérifien, Rabat, Maroco, 112 pp.

WANG Q. \& Millar J.G. 1997: Reproductive behavior of Thyanta pallidovirens (Heteroptera: Pentatomidae). - Ann. Entomol. Soc. Am. 90: 380-388.

WeInsteIn A. 2014: http://insectour.blogspot.co.il/2009/12/blogpost.html\#axzz3DYcxXnHU [Online]. [Accessed 14 April 2014].

WiLKInson D.S. 1926: The Cyprus processionary caterpillar (Thaumetopoea wilkinsoni, Tams). - Bull. Entomol. Res. 17: 163-182.

Willis J.C. 1988: A Dictionary of the Flowering Plants and Ferns, Cambridge University Press, Cambridge, UK, 712 pp.

Received November 5, 2014; revised and accepted January 20, 2015 Prepublished online February 16, 2015
Appendix 1. List of the host plant of Stenozygum coloratum other than those belonging to the Capparaceae. Previously published data on these plants indicates they are used only for feeding, therefore they were not included in the host list in Table 3. However, data from the present study suggest that some of these plants are suitable or partially suitable for nymphal development (see text).

\begin{tabular}{lccc}
\hline Family & Species & Area & Source* \\
\hline Actinidiaceae & Actinidia deliciosa & Israel & $\mathrm{A}$ \\
Anacardiaceae & Mangifera indica & Israel & $\mathrm{A}$ \\
Brassicaceae & Brassica sp. & Israel & $\mathrm{A}, \mathrm{B}$ \\
& Raphanus sp. & Israel & $\mathrm{A}, \mathrm{B}$ \\
& Sinapis sp. & Turkey & $\mathrm{C}$ \\
Ebenaceae & Diospyros sp. & Israel & $\mathrm{A}$ \\
Lauraceae & Persea americana & Israel & $\mathrm{A}$ \\
Moraceae & Ficus carica & Israel & $\mathrm{A}, \mathrm{B}$ \\
Proteaceae & Macadamia sp. & Israel & $\mathrm{A}$ \\
Rosaceae & Eriobotrya japonica & Israel & $\mathrm{A}$ \\
Rutaceae & Citrus sp. & Israel & $\mathrm{A}, \mathrm{B}$ \\
Solanaceae & Solanum melongena & Israel & $\mathrm{B}$ \\
& Solanum lycopersicum & Israel & $\mathrm{B}$ \\
& Capsicum sp. & Cyprus & $\mathrm{D}$ \\
Vitaceae & Nicotiana sp. & Israel & $\mathrm{A}, \mathrm{B}$ \\
& Vitis sp. & Israel & $\mathrm{A}, \mathrm{B}$ \\
\hline
\end{tabular}

* Source literature: A - Swirski et al. (2002); B - Avidov (1961); C - Lodos et al. (1998); D - Derjanschi \& Péricart (2005). 